\title{
Desmids from Lake Nabugabo (Uganda) and adjacent peat bogs
}

\author{
Alfred van GeEst $^{1} \&$ Peter CoeseL ${ }^{2}$ \\ ${ }^{1}$ De Wittenkade 156, NL-1051 AN Amsterdam, The Netherlands \\ ${ }^{2}$ Institute for Biodiversity and Ecosystem Dynamics, University of Amsterdam, Postbus 94248, NL-1090 GE \\ Amsterdam, The Netherlands
}

\begin{abstract}
In 2006 the desmid flora of Lake Nabugabo and some adjacent peat bogs was studied. All in total some 108 taxa were identified. Fourteen taxa, most of them being only known from the African continent, are discussed in detail. Six taxa are newly described: Euastrum gemmatum var. quadrituberosum, Micrasterias stuhlmannii var. nabugabonum, Cosmarium nabugabonum, Xanthidium thomassonii, Staurodesmus eckertii var. africanus and Staurastrum capitulum var. foersteri. The morphological variation found in Staurastrum longicolle is discussed in the light of possible speciation of desmids in a limnetic environment.
\end{abstract}

Key words: new desmid taxa, Uganda, species diversity, ecology, plankton

\section{Introduction}

In July 2006 the first author visited Lake Nabugabo in Uganda (East Africa) to collect samples for a taxonomic and biogeographical study of desmids. This shallow lake lies almost exactly on the equator, about $100 \mathrm{~km}$ south-east of Kampala, the capital of Uganda. It is a satellite lake of Lake Victoria and separated from this lake by a sand bar of only $2 \mathrm{~km}$ wide. The size is approx. 5 by 8 $\mathrm{km}$. Situated at an altitude of approx. $1140 \mathrm{~m}$ it is more or less between lowland and the mountain region but the climate is still tropical. The average minimum temperature for this part of Uganda does not drop below $15^{\circ} \mathrm{C}$ and the average maximum temperature fluctuates year round very little between 25 and $30^{\circ} \mathrm{C}$ (CHENG 2006).

The lake has been isolated from Lake Victoria for several thousands of years and hosts a few fish species that are not found in Lake Victoria. The lake as well as the surrounding swamps are poor in nutrients and support a high diversity of plant species. Lake Nabugabo is one of the few places in Uganda where swimming is popular as the lake has a reputation of being free of Schistosomiasis (Bilharzia). This is often related to the scarcity of molluscs that act as an intermediate host of this parasite. It could be connected to the low level of ions, especially calcium, which is needed by molluscs for the development of their calcareous shells (EFITRE et al. 2001; CHAPMAN et al. 2001). In 2004 the lake and its surroundings were designated as a RAMSAR-site (protected area). At this moment the lake is still used for fishery and the area around it for grazing cattle and crop cultivation (RAMSAR 2003).

For two reasons this lake is interesting for collecting desmids. The first reason is that the lake is surrounded by a boggy area with a vast vegetation of peat moss (Sphagnum). In Europe and North-America Sphagnum-dominated habitats are widespread and thoroughly investigated. Coesel \& Meesters (2007) who distinguish five different desmid communities for the Netherlands recognize even a separate community for this type of habitat. In tropical lowlands, however, these areas are very rare (VAN BREEMEN 1995). This can be the reason of the low number of publications dealing with tropical Sphagnuminhabitating algae, but it can also have to do with the preferences of hydrobiologists to sample large water bodies instead of shallow pools. It is not ruled out that desmid species described in taxonomic publications can originate from these habitats but that this is not explicitly mentioned in the text.

The special status of Lake Nabugabo is also emphasized by its phytoplankton composition. An analysis that was carried out in 2004 revealed that the plankton was dominated primarily by desmids, while the plankton of 10 other satellite lakes of Lake Victoria was dominated by cyanobacteria (KLING et al. 2006). Actually, most desmid species are benthic organisms and prefer densely 
vegetated water bodies. Some species, however, can lead a more or less free-floating existence due to the movement of water (tychoplankton) but will settle down as soon as water turbulence decreases. Euplanktonic species are a rarity among desmids (BROOK 1981) and lake plankton quantitatively dominated by desmids is but incidentally met with. Due to manmade eutrophication of lakes throughout the world, phytoplankton that consists mainly of desmids is becoming even rarer; therefore collecting plankton samples from Lake Nabugabo was a second good reason to visit this site.

There are hardly any published references to the desmid flora of this lake. LIND (1971) sampled swampy sites beside the road from Masaka to Bukakata near Lake Nabugabo, but does not mention plankton samples from the lake itself or samples taken from Sphagnumdominated habitats. Other papers on Lake Nabugabo are mainly focussed on fish species in relation to fishery and a small minority refer to macrophytes. One publication (EFITRE et al. 2001) deals with macroinvertebrates and does provide some ecological information that can be relevant for further desmid research. The present paper describes the desmid flora of both the proper lake and the adjacent Sphagnum bogs. A number of species is taxonomically and biogeographically discussed in more detail.

\section{Material and Methods}

Sampling sites were located at the northern shore of Lake Nabugabo (Fig. 1). Plankton samples were collected with a plankton net (mesh size $50 \mu \mathrm{m}$ ) from a small boat, about 50 meters from the shore. Benthos samples where gathered by squeezing submerged Sphagnum by hand and catching the residue in a small bottle. This moss was taken from a small boggy zone of Sphagnum just behind a zone of high grasses that fringed the lake shore. One sample was taken by squeezing out the roots of reed-like grasses that contacted the lake water. Samples were fixed with formaldehyde to a final concentration of about $4 \%$ on the day of collection, but some fresh samples were brought back to the Netherlands for studying the live content. Geographic co-ordinates were recorded with a GPS (which also measured a height of 1137-1142 $\mathrm{m})$. Conductivity of the water sampled was measured with a simple portable meter and a conductivity of 10 $30 \mu \mathrm{S} . \mathrm{cm}^{-1}$ was measured for all samples $\left(10 \mu \mathrm{S} . \mathrm{cm}^{-1}\right.$ being the lowest measurable value of the meter). In the present investigation acidity was not measured. EFITRE et al. (2001) give values between $\mathrm{pH} 6.0$ and $\mathrm{pH} 7.1$ for the lake water and LiND (1971) a pH 5.8 for the swampy soil beside the road from Masaka to Bukakata, north of Lake Nabugabo. EFITRE et al (2001) give an average depth of the lake bottom of $4.5 \mathrm{~m}$. and a water transparency of $0.5-0.8 \mathrm{~m}$. On the (windy) visit of Lake Nabugabo by the first author, the bottom was not visible.

Specification of the samples:

2007-015, Lat. $0^{\circ} 20^{\prime} 38.5 ”$ S, Long. $31^{\circ} 53$ ' 11.6” E, net sample

2007-016, Lat. $0^{\circ} 20^{\prime} 38.5 ”$ S, Long. 31 ${ }^{\circ} 53$ ' 11.6” E, net sample

2007-017, Lat. $0^{\circ} 20^{\prime} 38.5$ ” S, Long. $31^{\circ} 53^{\prime} 11.6$ ” E, submerged roots of reed

2007-018, Lat. $0^{\circ} 20^{\prime} 37.4$ " S, Long. 31 ${ }^{\circ} 53^{\prime} 05.2$ " E, Sphagnum

2007-019, Lat. $0^{\circ} 20^{\prime} 37.4 ”$ S, Long. 31 ${ }^{\circ} 53^{\prime} 05.2^{\prime \prime} \mathrm{E}$, Sphagnum

2007-020, Lat. $0^{\circ} 20^{\prime} 37.4 ”$ S, Long. 31 ${ }^{\circ} 53^{\prime} 05.2 ”$ E, Sphagnum

2007-021, Lat. $0^{\circ} 20^{\prime} 22.5^{\prime}$ ' S, Long. 3153’26.1” E, Sphagnum

2007-022, Lat. $0^{\circ} 20^{\prime} 23.1 ”$ S, Long. 31 ${ }^{\circ} 53$ ' 26.5” E, Sphagnum

The scanning electron microscopy (SEM) images have been made with the use of a Phenom desktop microscope. Sample material was placed on glass coverslips that were coated three times with a $10 \%$ solution of poly-L-lysine. After dehydration in aceton series $(30 \%, 50 \%, 70 \%, 2 \times 90 \%, 2 \times 95 \%, 2 \times 100 \%)$ the material was dried with liquid $\mathrm{CO}_{2}$ and sputtercoated with gold.

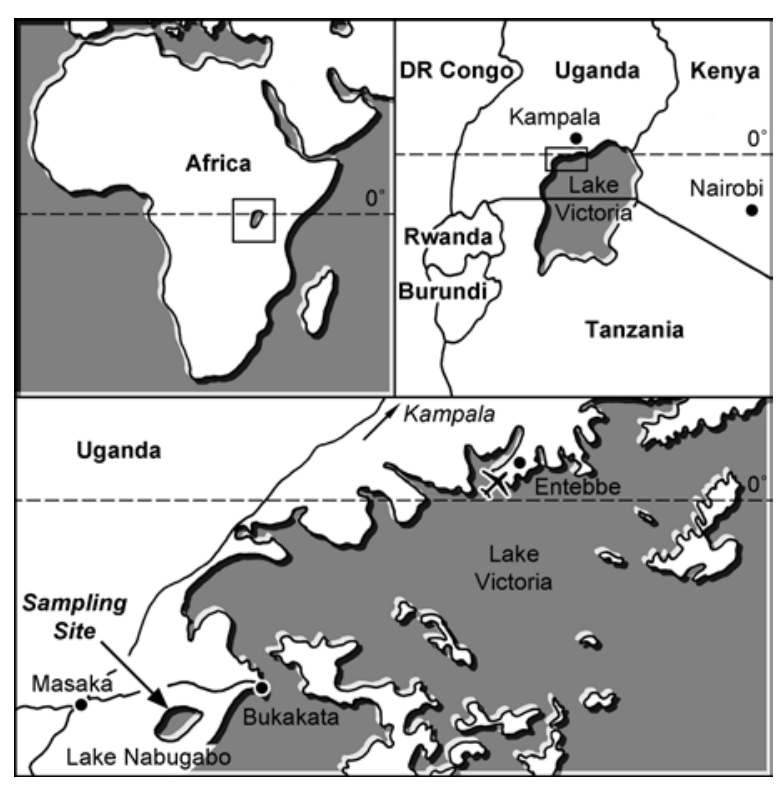

Fig. 1. Map of Africa, Lake Victoria and the sampling site location. 


\section{Results}

Analysis of the two samples taken with a net from the main body of Lake Nabugabo shows that desmids are indeed the most dominant organisms of the plankton (at least for that particular moment!). Cyanobacteria follow at some distance in second place (Fig. 2). It is maybe of interest to mention that no protozoans or multicellular animals (crustaceans, etc.) were encountered in the (fresh) plankton samples, although the presence of obscure unicellular plant or animal species that belong to other groups than desmids or blue-green algae may be overlooked. It seems safe to say that at least $95 \%$ of the specimens gathered by the plankton net do belong to desmids and blue-greens.

A closer look at the composition of the desmid fraction learns that it consists of just a few species, approx. 10, and that they all have a relatively small cell size $(<50 \mu \mathrm{m})$. It is interesting to compare this species number with the one found in the only sample that was taken from the lake shore. This sample (2007-017) was collected by squeezing out the roots of reed-like grasses that were exposed directly to the lake water. It contained approx. 25 species, among which larger ones. This difference in desmid diversity between the two sampling places shows once more the preference of desmids to a more benthic way of life.

The predominant desmid species in the net samples was Staurastrum longicolle (see the taxonomic account of the present paper). Other abundant species were Staurastrum arcuatum NorDST., Staurodesmus omearae (W.ARCHER) TEILING and Staurodesmus dejectus (RALFS) TEILING; all specimens had cell dimensions close to the smallest sizes mentioned in literature. St. longicolle was also abundant in the reed sample but totally absent in the Sphagnum samples. The other, less abundant, species were very small. A number of them, mainly representatives of the genera Cosmarium (maybe even Cosmocladium) and Staurastrum were but little characteristic and could not be identified. All planktonic species showed thready extrusions radiating from the cell body. These extrusions are probably part of a gelatinous envelope that surrounds the whole body of the cell and helps the cells to stay suspended in the water column or hinder predation by zooplankton (COESEL 1994). These envelopes were difficult to see under the (light) microscope but the fact that all specimens stayed neatly on a certain distance from each other is probably due to this envelope. Benthic species, for that matter, can also have gelatinous envelopes.

Analysis of the four Sphagnum samples produced some 81 different desmid taxa among which Actinotaenium cucurbita (RAlfs) TeILIng, Actinotaenium wollei (W. et G.S.WeST) RŮŽIČKA et Pouzar, Tetmemorus laevis RAlfs and Haplotaenium minutum (RALFS) BANDO were the predominant ones. Somewhat less abundant were Euastrum praemorsum (NoRDST.) SCHMIDLE, Xanthidium mucronulatum (NORDST.) COUTÉ et Tell, Netrium digitus Itzigs. et Rothe, Cosmarium pyramidatum W.ARCHER, Bambusina borreri (RAlfs) Cleve, Desmidium graciliceps (Nordst.) Lagerheim and Staurastrum wildemanii Gutw. For a number of rather incidentally encountered, but taxonomically and biogeographically more interesting taxa, see taxonomic account below.

\section{Taxonomic account}

Because of huge difficulties to trace and examine type specimens of desmid taxa in the original sample material, in the taxonomic account below, for all synonyms provided, illustrations making part of the original description are considered the type material (holotype). As, moreover, it is almost unfeasonable to preserve a single cell as a type specimen, according to art. 37.5 of the Vienna Code (McNeILl et al. 2006) in the present paper names of new taxa are connected to illustrations as well.

\section{Actinotaenium angulatum (W. et G.S.WEST) RŮŽIČKa et PouZar}

Folia Geobot. Phytotax. 13: 41 (1978).

Basionym: Cylindrocystis angulata W. et G.S.WEST

Trans. Linn. Soc. London, Bot. 5: 237, pl. 13: 25, 26 (1896).

var. brasiliense (GRönblad) RŮžıčKa et PouZar (Figs 3-4, 13-14)

Folia Geobot. Phytotax. 13: 42 (1978).

Basionym: Cosmarium floridanum LÜTKEM. var. brasiliense GRÖNBLAD

Acta Soc. Sci. Fenn., Ser. B, Opera Biol. 2 (6): 18, pl. 6: 108, 109 (1945).

Synonym: Actinotaenium tumidum var. brasiliense (GrönBlad) TeILING

Bot, Not. 107: 402, fig. 52 (1954). 
Actinotaenium angulatum is marked by fairly large cells. Semicells are conical in shape with about straight sides, a truncate apex and rounded apical angles (Förster 1982). A. angulatum was originally described from North America (WEST \& WeST 1896), var. brasiliense from Brazil (GRÖNBLAD 1945). According to FöRSTER (1.c.) the main difference between the nominate variety and var. brasiliense would lie in the slenderness of the cells (i.e., L/B ca. 2.3 in var. angulatum versus ca. 3 in var. brasiliense). However, when considering the original diagnoses, there could also be a difference in cell wall sculpture. Whereas WEST \& WEST (1.c.) characterize the cell wall in the nominate variety as scrobiculate-punctate, GRÖNBLAD (1.c.) makes mention, in var. brasiliense, of a subtilely porose wall. If that difference would appear to be reliable and consistent, we might have to do with separate species.

Anyhow, our Nabugabo material is characterized by relatively slender cells (L/B 2.7-3.5) with very fine cell wall pores, so fully in accordance with the diagnosis of var. brasiliense. Cell wall pores in most part of the cell are more or less scattered, but those at the base of the semicell are arranged in a supraisthmial whorl (Fig. 3) whereas a big, deepened apical pore field may be observed (Fig. 14). FÖRSTER (1.c.) does mention the supraisthmial ring but not the big apical pore. GRÖNBLAD (1945) does not mention or depict such an apical pore either, contrary to KRIEGER (1950) and Bourrelly \& Couté (1991). As the central, apical pore in question (connected to a pit in the cell wall) depending on the position of the cell is not always quite obvious, it might have been overlooked in a number of cases.

Up to then, A. angulatum var. brasiliense has only been recorded from South America and Africa. On the Nabugabo site, it was frequently encountered in all the Sphagnum samples.

\section{Euastrum gemmatum BrÉBISSON ex RALFS}

British Desmidieae: 214, pl. 35: 25 (1848).

var. quadrituberosum CoESEL et VAN GEEST var. nov. (Fig. 15)

Diagnosis: A varietate typica protuberationibus 4, contra 3 ad centrum semicellularem lateraliter lobo mediano duplicato differt. Cellularum longitudo 52-58 $\mu m$, latitudo 34-36 $\mu \mathrm{m}$, crassitudo 21-24 $\mu \mathrm{m}$, isthmi latitudo 8-11 $\mu$ m. - Typus: Figura nostra 15.

Differs from the nominate variety in frontal view by the occurrence of four instead of three protuberances in the semicell centre, in lateral view by a doubled median lobe. Cell length 52-58 $\mu \mathrm{m}$, cell breadth $34-36 \mu \mathrm{m}$, cell thickness $21-24$ $\mu \mathrm{m}$, breadth of isthmus 8-11 $\mu \mathrm{m}$. - Type: our Fig. 15. Type locality: shore of Lake Nabugabo, Uganda (sample 2007-021), A. van Geest, July 28, 2007.

Euastrum gemmatum as depicted by RALFS (1848) and in the European floras by WEST \& WEST (1905) and RŮŽǏČKA (1981) is characterized by a transversal series of three protuberances at the base of the semicell. Our newly described variety is marked by an additional, equally sized tumour just above the supraisthmial one. In addition to that, the median lateral lobe is doubled so that, all in total, each semicell is marked by 18 protuberances (lobes and tumours) versus 14 in the nominate variety (compare our Figs 15 and 16. In respect of that feature it resembles $\mathrm{Eu}$. gemmatum var. ornatum as described by BourRelly \& Couté (1991) from Madagascar which, however, is marked by five instead of four facial protuberances. It should also be compared with Eu. gauthierii (including forma bifidum) as described by Bourrelly (1957) from Mali (formerly French Sudan). This latter species differs from $E u$. gemmatum by its much more pronounced facial protuberances, particularly to be seen in apical view. No doubt, all abovementioned taxa are closely affiliated, they just differ in the number and markedness of their facial protuberances.

Whereas from Europe only the nominate variety of Eu. gemmatum is known, the other, more exuberantly shaped taxa mentioned above have only been recorded from tropical Africa. On the Nabugabo site, Eu. gemmatum var. quadrituberosum was frequently encountered, next to the nominate variety, in samples 2007-021 and 2007-022 (both Sphagnum).

Euastrum pseudopectinatum SCHMIDLE (Fig. 17)

Bot. Jahrb. Syst. 26: 46, pl. 2: 39 (1898).

Euastrum pseudopectinatum differs from Eu. pectinatum RALFS in that its apical lobe is more strongly dilate with distinctly recurved apical angles, whereas the outline of the basal part is trapeziform rather than rectangular(KRIEGER 1937). Eu. pseudopectinatum was described by SCHMIDLE (1898) from the island of Zanzibar. Later on, that same author described Eu. pseudopectinatum 
var. evolutum, marked by indented basal and lateral lobes and wanting tubercles at the apical angles, from Lake Nyasa (Schmidle 1902). WeSt (1907) represented, under the name of just $E u$. pseudopectinatum, an algal form comparable with our one from a swamp in present-day Tanzania. In the present investigation Eu. pseudopectinatum, apart from Lake Nabugabo, was also found some $70 \mathrm{~km}$ NE from the Nabugabo site (i.e. Mamamba swamp). When considering the morphological variability as shown by specimens from both sites (Fig. 17 from the Nabugabo site and Fig. 18 from the Mabamba site) there seems to be insufficient ground to distinguish a separate var. evolutum indeed.

Eu. pseudopectinatum is only known from eastern Africa. On the Nabugabo site, it was frequently encountered in all the Sphagnum samples.

\section{Micrasterias doveri BISWAS}

J. Fed. Malay States Mus. 14 (3/4) : 421, pl. 12: 36 (1929).

\section{var. africanum Bourr. (Fig. 19)}

Bull. Inst. Franç. Afr. Noire, Sér. A. 23 (2): 337, 358, pl. 16: 1-3 (1961). Typus: Tabula 16: 3.

We herewith validate the name of the abovementioned variety because in the above paper indication of a nomenclatural type is wanting (Art. 37.1 ICBN).

Actually, the algal form under discussion is intermediate between Micrasterias doveri BIswAS and M. torreyi var. curvata WILLI KRIEG.. Therefore it is not surprising that it may be encountered in literature under both names (e.g., VAN OYE 1953; Opute 1992). KRIEGER (1939) placed M. doveri as var. doveri under $M$. torreyi BAILEY ex RALFS. When comparing, however, the original figures of M. torreyi (var. torreyi), M. torreyi var. curvata and $M$. doveri as reproduced in KRIEGER (1939), the similarity between $M$. torreyi var. curvata and $M$. doveri is much more obvious than between $M$. torreyi var. curvata and $M$. torreyi var. torreyi. This was also noticed by Thomasson (1960) and Bourrelly (1961). Consequently, Thomasson (1986) formally transferred var. curvata from $M$. torreyi to $M$. doveri. It is questionable however, taking $M$. doveri as a separate species, whether M. doveri var. curvata deserves the status of a separate variety next to $M$. doveri var. africanum. Mutual differences are so small that it is often hard to make a choice.
Whereas $M$. doveri var. africanum is particularly recorded from African countries (BouRRELlY 1961; Lind 1971; Bourrelly \& Couté 1991; Opute 1992), M. doveri var. curvata, as well as some other closely affiliated varieties are known from tropical Asia, Australia and South America as well. On the Nabugabo site, M. doveri var. africanum was frequently encountered in all the Sphagnum samples.

\section{Micrasterias stuhlmannii HIERON.}

Engler, Pflanz. Ost-Afr. C: 21 (1895).

var. nabugabonum Coesel et VAN Geest var. nov. (Figs 20-21)

Diagnosis: A varietate typica lobulis lateralibus minus gracilibus et dissimilibus differt. Cellularum longitudo 172-192 $\mu \mathrm{m}$, latitudo 132-152 $\mu \mathrm{m}$, isthmi latitudo 26 um. - Typus: Figura nostra 20.

Differs from the nominate variety by less slender and less differentiated lateral lobules. Cell length 172-192 $\mu \mathrm{m}$, cell breadth $132-152 \mu \mathrm{m}$, breadth of isthmus $26 \mu \mathrm{m}$. - Type: our Fig. 20. Type locality: shore of Lake Nabugabo, Uganda (sample 2007018), A. van Geest, July 28, 2007.

The most striking feature in the Micrasterias form depicted in our figures, is the outline of the upper part of the apical lobe, i.e., dilated, the dorsal side showing a median depression and recurved, dentate extremities. In respect of that, there is some resemblance with given forms of $M$. conferta P.LundeLl, $M$. tetraptera W. et G.S.WEST and $M$. cunningtonii G.S.WEST which, however, are characterized by a much stronger dilatation of the apical lobe. A better fit is found in M. stuhlmannii Hieron. as depicted by SCHMidLe (1898). SCHMidLE (1.c.) based his illustrations on material that he got from Adolf Engler and Georg Hieronymus. The material in question was collected by Franz Stuhlmann and Georg Volkens from Tanzania. HieronYMus (1895) described M. stuhlmannii without providing any illustrations but as SCHMIDLE studied the same material as Hieronymus did, it is almost certain that SCHMIDLE's pictures refer to the same species.

Our newly described var. nabugabonum differs from the nominate variety in that the lateral lobules are less slender. Moreover, whereas differentiation of the lateral lobules in var. nabugabonum is not further than to the third order, the picture of the nominate variety in SCHMidLE (1898, pl. 3: 15) shows also some lobules of the fourth order. Bourrelly (1961) classed M. 


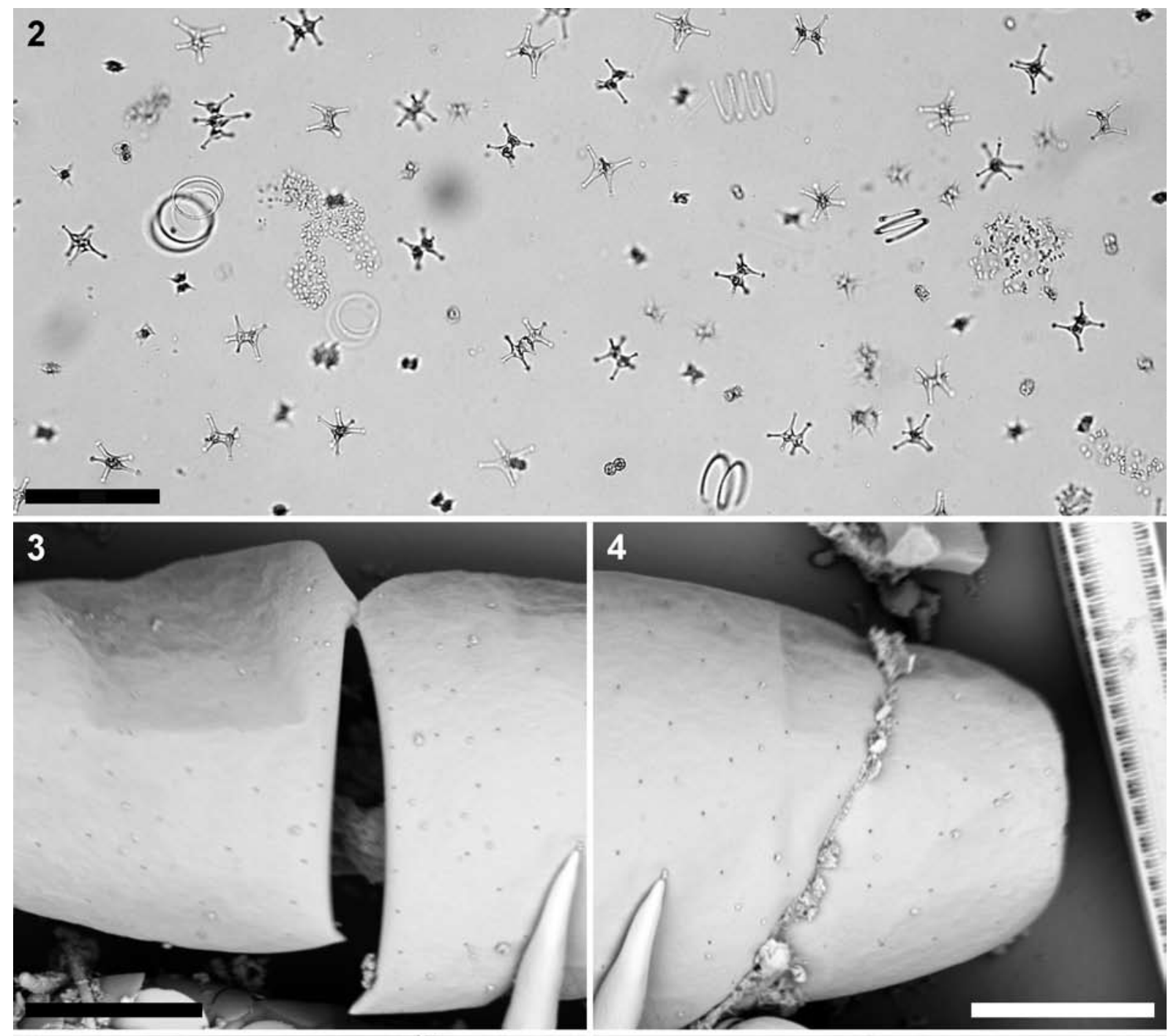

5

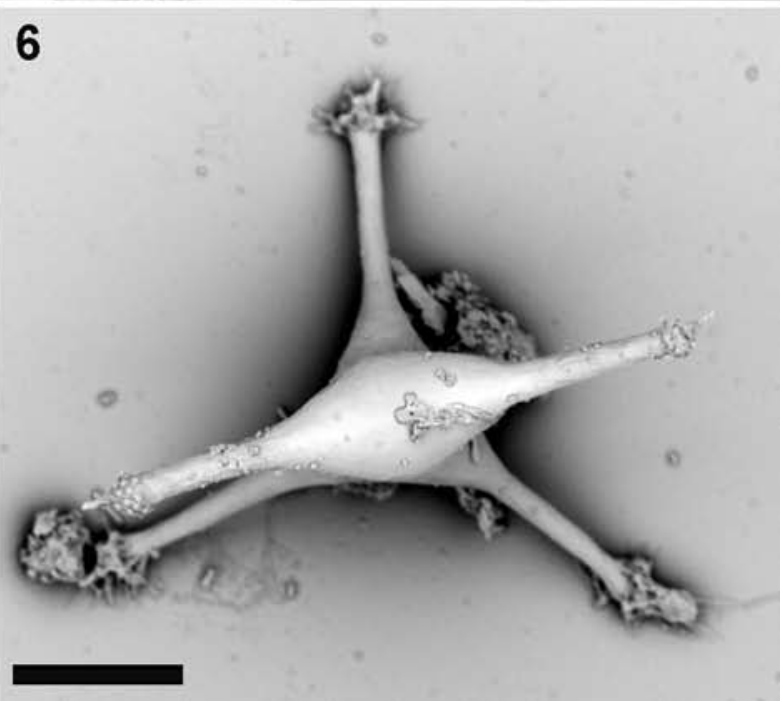

Figs 2-6. (2) Net plankton of Lake Nabugabo predominated by the desmid Staurastrum longicolle and some blue-greens (presumably Microcystis sp. and Planktolyngbia sp.); (3-6) SEM photographs: (3-4) Actinotaenium angulatum var. brasiliense; (5) Staurastrum trihedrale in apical view; (6) Staurastrum longicolle with reduced terminal spines and instead of that many terminal mucilage extrusions. Scale bar $100 \mu \mathrm{m}$ (for 2), $10 \mu \mathrm{m}$ (for 3-6). 

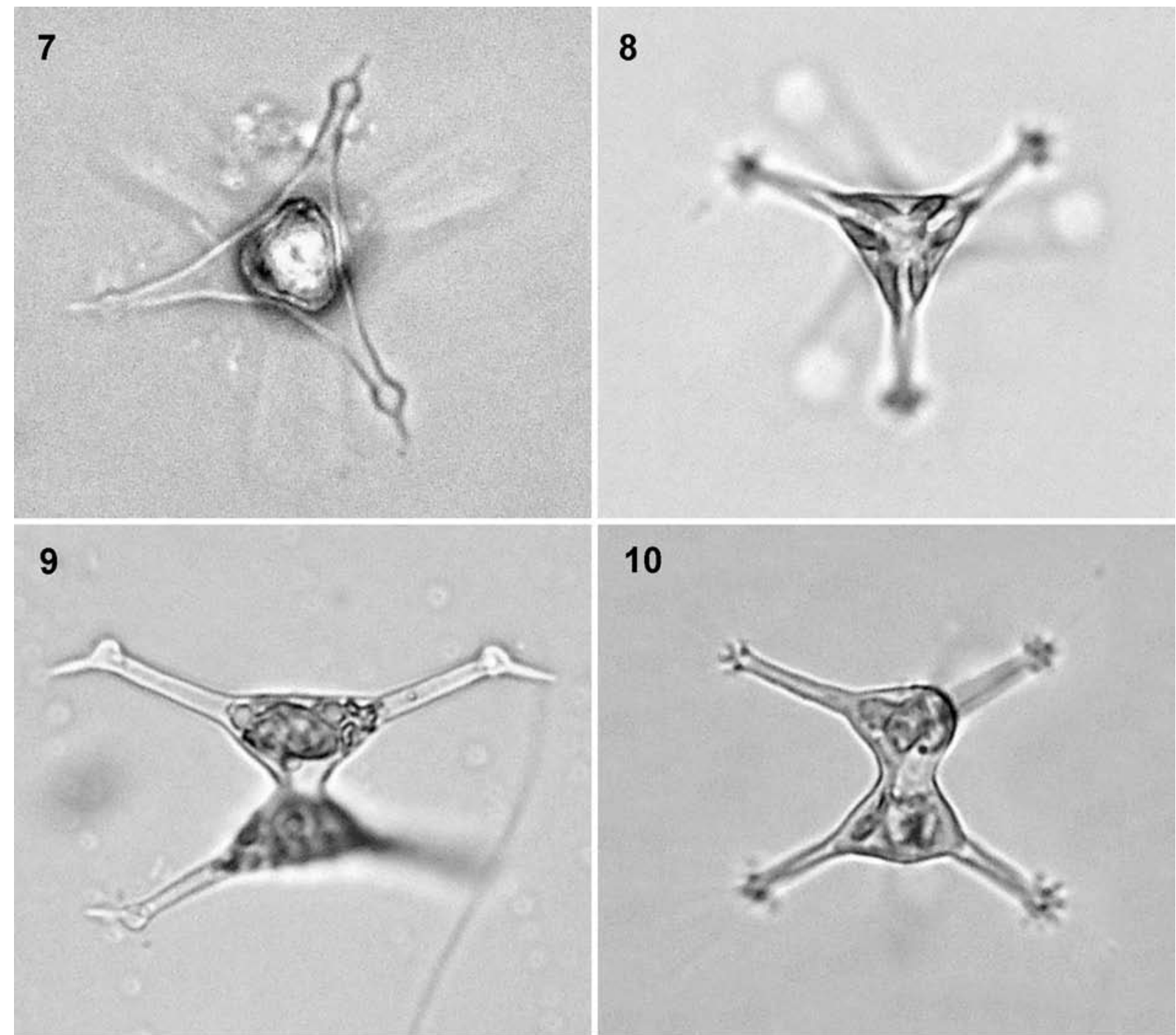

\section{0}

11

12
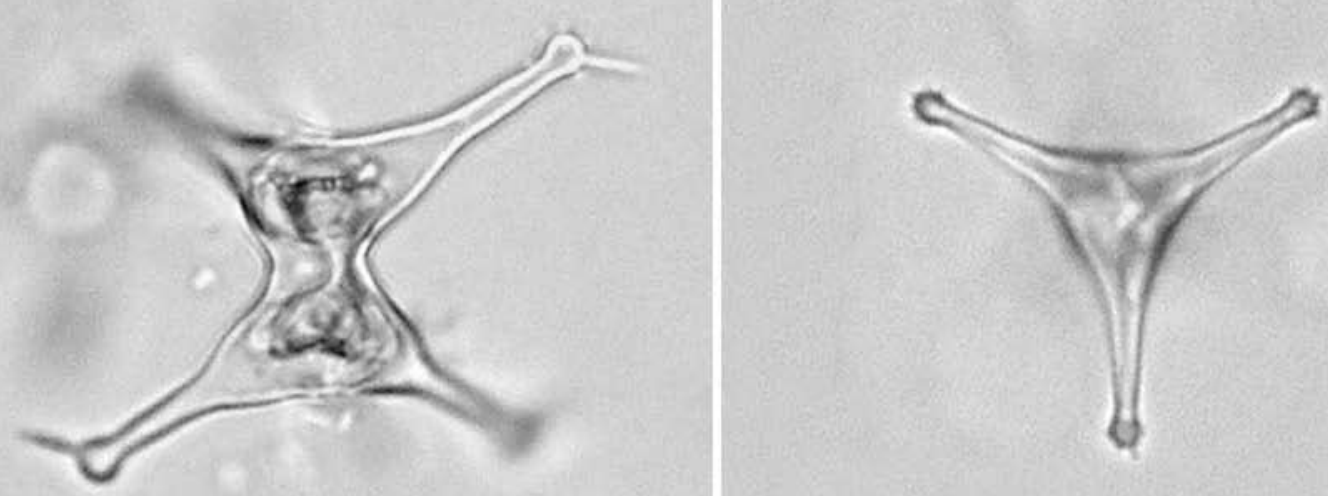

Figs 7-12. Light photographs of Staurastrum longicolle from benthic (left hand series) and limnetic (right hand series) environment. Scale bar $10 \mu \mathrm{m}$. 


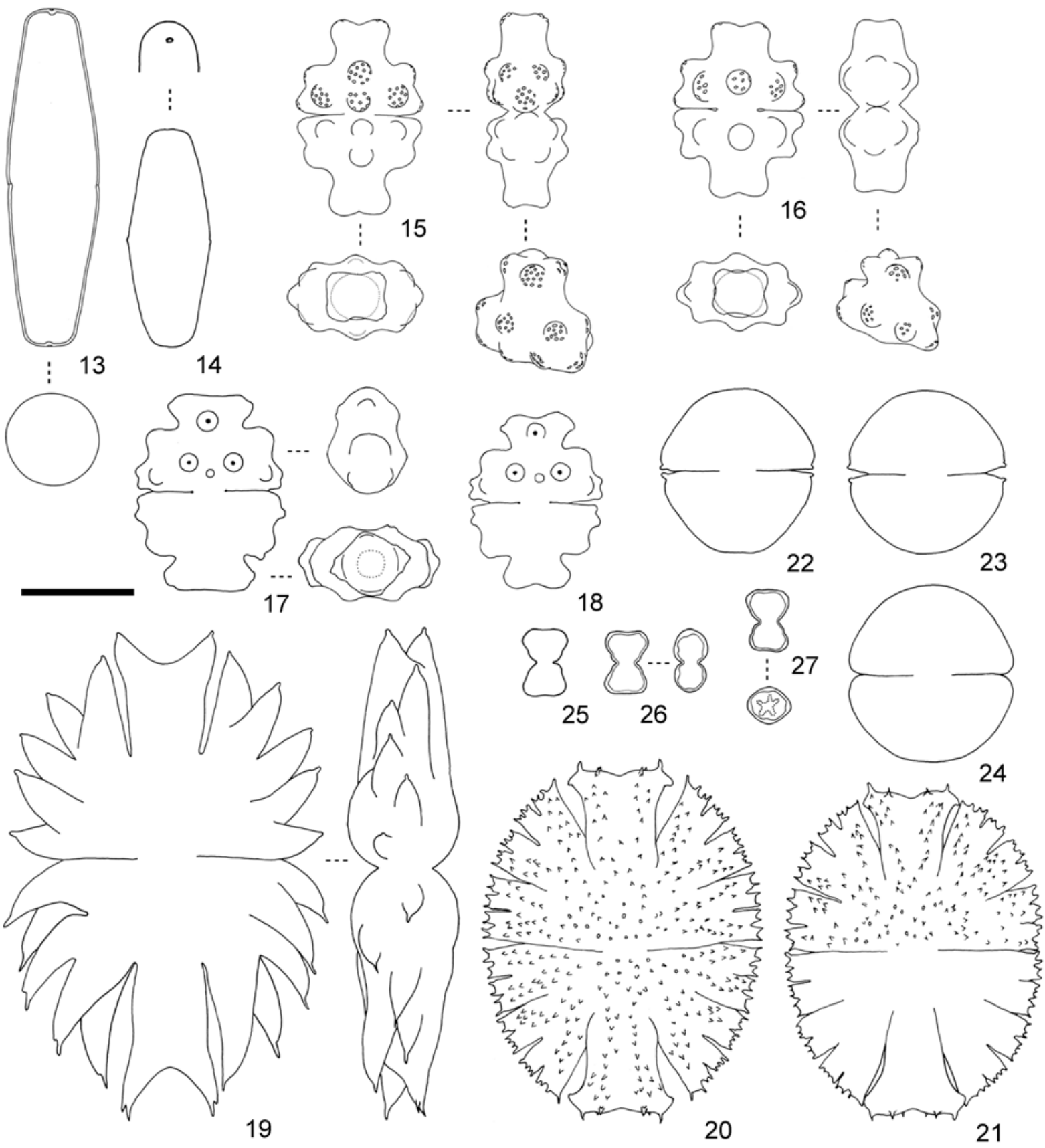

Figs 13-27. (13-14) Actinotaenium angulatum var. brasiliense; (15) Euastrum gemmatum var. quadrituberosum; (16) E. gemmatum var. gemmatum; (17-18) E. pseudopectinatum; (19) Micrasterias doveri var. africanum; (20-21) M. stuhlmannii var. nabugabonum; (22-24) Cosmarium maximum var. latum; (25-27) C. nabugabonum. Scale bar 30 um (for 13-18, 25-27), $60 \mu \mathrm{m}$ (for 19-24).

stuhlmannii as a variety of $M$. apiculata RALFS but in our opinion M. stuhlmannii does represent a species of its own. As far as could be traced, $M$ stuhlmannii is only known from Africa (SCHMIDLE 1898; Bourrelly 1961; Lind 1971, Bourrelly \& Couté 1991). On the Nabugabo site, $M$. stuhlmannii var. nabugabonum was infrequently encountered in samples 2007-018 and 2007-020 (both Sphagnum).

\section{Cosmarium maximum (BÖRGESEN) W. et} G.S.WEST

J. Bot. 35: 114 (1897).

var. latum A.M.ScotT (Figs 22-24)

Acta Bot. Fenn. 66: 20, pl.10: 224-226 (1964). Typus:

Tabula 10: 225 . 
We herewith validate the name of the abovementioned variety because in the above paper indication of a nomenclatural type is wanting (Art. 37.1 ICBN).

Cosmarium maximum was originally described by BøRgesen (1890) from Brazil as a variety of C. obsoletum (Hantzsch) Reinsch. To our mind, WeST \& WeST (1897) justly raised it to species level, not only owing to larger cell dimensions, but mainly because of a much deeper constriction of the cell (as compared with $C$. obsoletum). SCOTT, in GrönBLAD et al. (1964) described C. maximum var. latum from Uganda, differing from the nominate variety by a somewhat higher cell breadth/length ratio resulting into an almost circular cell outline. As is shown in our Fig. 24, the characteristic papillate projections on the basal angles sometimes are wanting. In that case, C. maximum var. latum may be confused not only with $C$. obsoletum, but also with $C$. lundellii Delponte, $C$. dorsitruncatum (NoRdst.) G.S.West, $C$. dorsitruncatiforme Gutw., C. circulare Reinsch, C. baileyi Wolle and, presumably, even more species.

C. maximum var. latum has only been recorded from Africa, i.e., Madagascar (Bourrelly \& Leboime 1946, as C. maximum) and Uganda (GRöNBLAD et al. 1964; Lind 1971, as Staurodesmus croasdaleae var. latus (A.M.Scott) Teiling) but in view of the high chance of confusion with other species a wider geographical distribution is not to be precluded. On the Nabugabo site, C. maximum var. latum was encountered frequently in all the Sphagnum samples.

\section{Cosmarium nabugabonum CoESEL et VAN GEEST sp. nov. (Figs 25-27)}

Diagnosis: Cellulae circa duplo longiores quam latae aliquantum profunde constrictae. Sinus V-formis. Semicellulae ambitu plusminusve cuneatae, apicibus et lateribus lateribus leviter concavis, angulis late rotundatis. Cellulae paries laevis. Semicellulae apicaliter visae rhomboideae, angulis late rotundatis incrassatis. Cellularum longitudo 17-18 $\mu \mathrm{m}$, latitudo 11-12 $\mu \mathrm{m}$, crassitudo 9-10 $\mu \mathrm{m}$, isthmi latitudo $5 \mu \mathrm{m}$. Typus: Figura nostra 27.

Cells about twice as long as broad, rather deeply constricted. Sinus V-shaped. Semicells in rough outline cuneate with broadly rounded angles and slightly concave apices and lateral sides. Cell wall smooth. Semicells in apical view rhomboid with broadly rounded angles. Cell wall thickened at the angles. Cell length 17-18 $\mu \mathrm{m}$, cell breadth 11-12 $\mu \mathrm{m}$, cell thickness $9-10 \mu \mathrm{m}$, breadth of isthmus 5 $\mu \mathrm{m}$. - Type: our Fig. 27. Type locality: shore of Lake Nabugabo, Uganda (sample 2007-022), A. van Geest, July 28, 2007.

At first glance, the above newly described species resembles Cosmarium helcangulare var. brasiliense WILLI KRIEG., exclusively known from a site in southeastern Brazil (KRIEGER 1950). Semicells in both taxa are in frontal view cuneate in outline with a slightly concave apex. However, whereas semicells in C. helcangulare var. brasiliense in apical view are about elliptic in outline, those in C. nabugabonum are thickset rhomboid. Anyhow, in our opinion, $C$. nabugabonum is not affiliated to $C$. helcangulare as originally described by NORDSTEDT (1888b) from the Danish island of Bornholm. Interestingly, both $C$. nabugabonum and $C$. helcangulare var. brasiliense were collected from Sphagnum pools. On the Nabugabo site, C. nabugabonum was frequently encountered in samples 2007-020 and 2007-022 (both Sphagnum).

\section{Xanthidium thomassonii Coesel et VAN GeEsT sp. nov. (Fig. 28-29)}

Diagnosis: Cellulae spinis exclusis frontaliter longiores quam latae profunde constrictae sinu aperto angulo acuto. Semicellulae circa hexagonae spinis duabus in quoque angulo apicali plerumque spina una in quoque angulo laterali et protuberatione papilliformi in quoque angulo basali. Cellulae paries aliter laevis. Semicellulae apicaliter visae late ellipticae polis acuminatis in spinas longas terminantes, corpus spinis quatuor intramarginalibus crucialiter ordinatis ornatus. Cellulae praeter spinos 43-47 $\mu$ m longae, 40$43 \mu \mathrm{m}$ latae. Isthmi latitudo 10-12 $\mu \mathrm{m}$. Spinae usque ad 19 um longae. - Typus: Figura nostra 28.

Cells exclusive of spines in frontal view longer than broad, deeply constricted with an open, acute-angled sinus. Semicells about hexagonal with two spines at each apical angle, generally one spine at each lateral angle and a papilla-like protrusion at each basal angle. Cell wall otherwise smooth. Semicells in apical view broadly elliptic, the acuminate poles ending in a long spine; the body with four, cruciately arranged intramarginal spines. Cell length without spines $43-47 \mu \mathrm{m}$, cell breadth without spines $40-43 \mu \mathrm{m}$, breadth of 

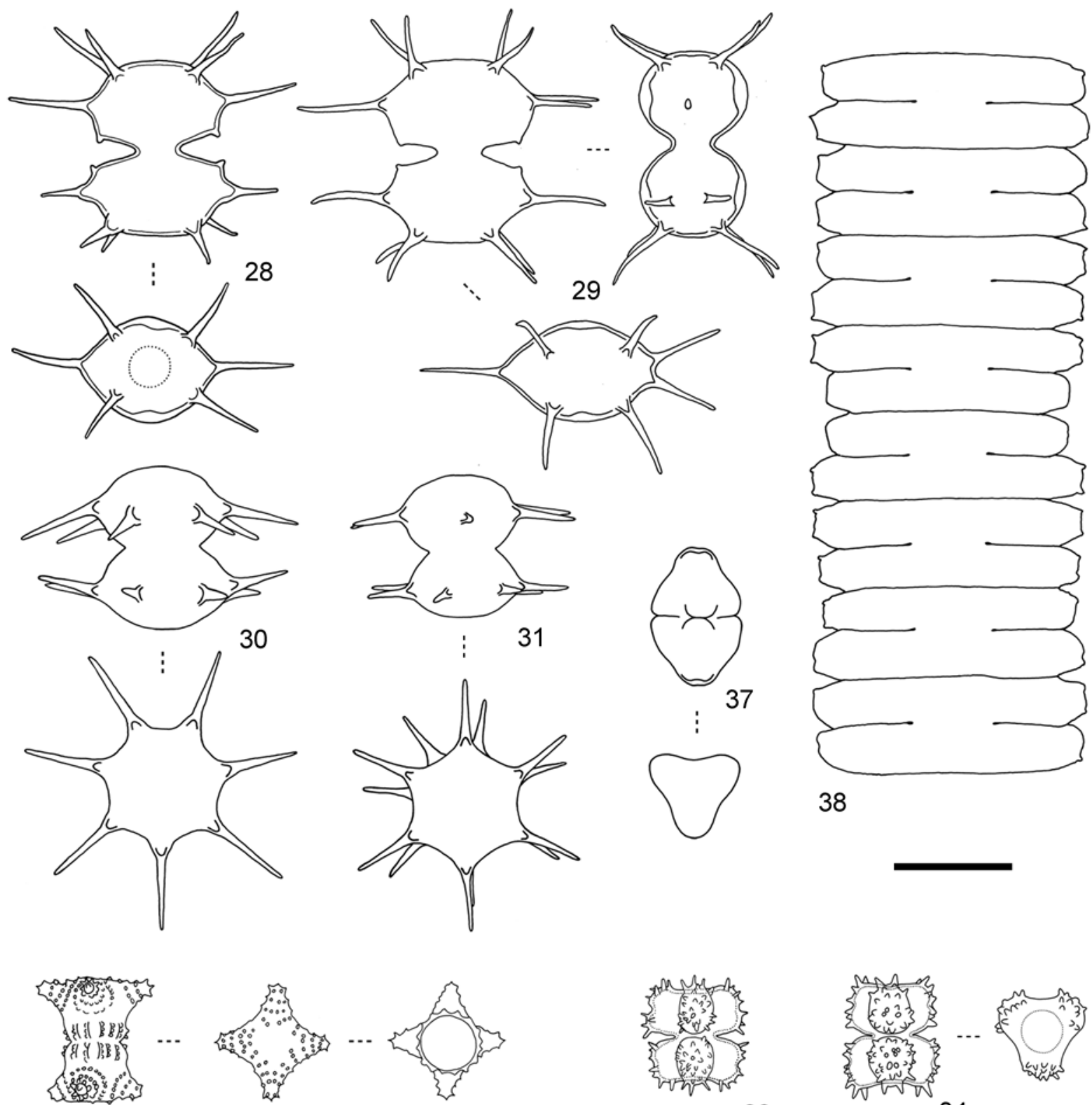

32
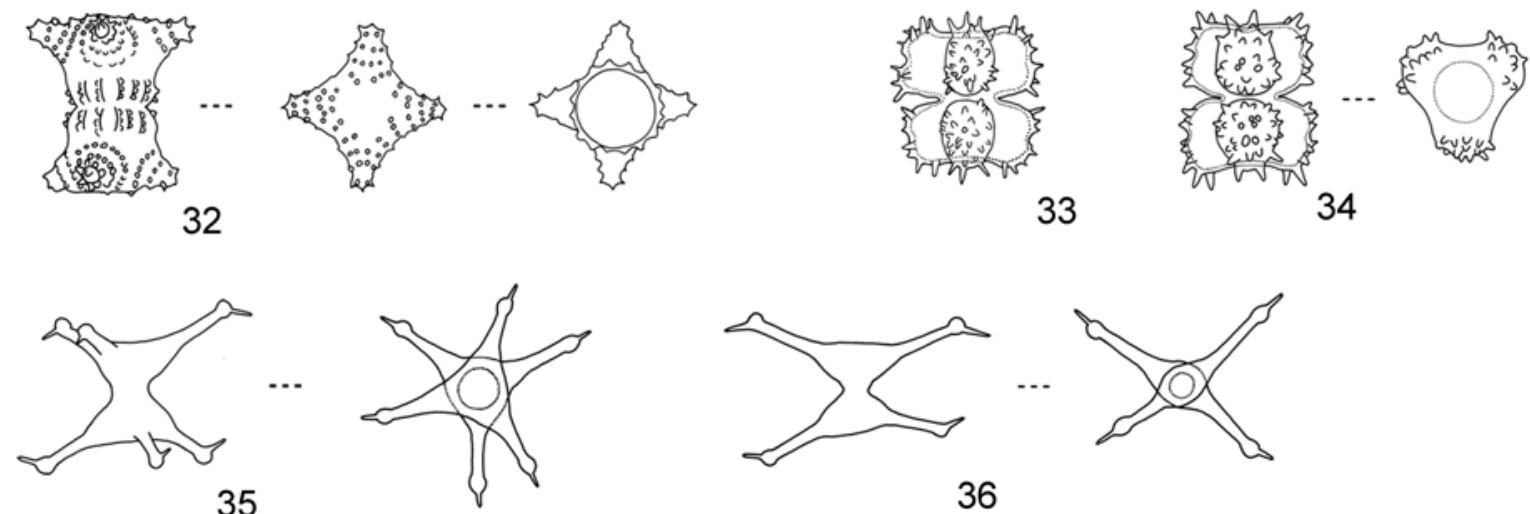

36

Figs 28-38. (28-29) Xanthidium thomassonii; (30-31) Staurodesmus eckertii var. africanus; (32) Staurastrum capitulum var. foersteri; (33-34) S. corbula var. pulchrum; (35-36) Staurastrum longicolle; (37) S. trihedrale; (38) Spondylosium rectangulare. Scale bar $30 \mu \mathrm{m}$ (for 28-37), $60 \mu \mathrm{m}$ (for 38).

isthmus 10-12 $\mu \mathrm{m}$. Maximum length of spines 19 $\mu \mathrm{m}-$ Type: our Fig. 28. Type locality: shore of Lake Nabugabo, Uganda (sample 2007-018), A. van Geest, July 28, 2007.

The above newly described species was depicted by Thomasson (1960, pl. 10: 18) under the name of Xanthidium antilopaeum var. pseudotropicum GRÖNBLAD. However, that variety, described by GRÖNBLAD (1945) from Brazil, in the outline of its semicells is essentially different from our alga 
under consideration. Although of Xanthidium antilopaeum tens of different varieties and formae have been described, none of those meets the illustration in THOMASSON (1.c.). In our opinion, many of those $X$. antilopaeum varieties and formae represent species of their own. Also in case of our taxon under discussion we prefer to render it the status of species rather than that of a variety. Like in many Xanthidium species the number of spines is not very fixed, the single spine at the lateral angles occasionally may be doubled (Fig. 29).

So far, $X$. thomassonii could only be traced from Zambia (Thomasson 1.c.). On the Nabugabo site, it was infrequently encountered in all the Sphagnum samples.

\section{Staurodesmus eckertii (Kurt FörSt.) TeILING}

Ark. Bot. 6 (11): 493 (1967).

Basionym: Staurastrum eckertii KURT FÖRST. Hydrobiologia 23: 419, pl. 34: 3, 4, pl. 49: 1 (1964). Typus: Tabula 34: 1.

We herewith validate the name of Staurastrum eckertii KURT FöRST. as in the above paper indication of a nomenclatural type is wanting (Art. 37.1 ICBN). The name of Staurodesmus eckertii (KURT FöRST.) TEILING is validated by providing a full and direct reference to FöRSTER's original publication (Art. 33.2 ICBN).

var. africanus Coesel et VAN Geest var. nov. (Figs 30-31)

Diagnosis: A varietate typica semicellulis ellipsoideis spinis (plusminusve) convergentibus differt. Cellulae praeter spinos 37-42 $\mu \mathrm{m}$ longae, 30-38 $\mu \mathrm{m}$ latae. Cellularum crassitudo 27-28 $\mu \mathrm{m}$. Spinae usque ad 18 um longae. - Typus: Figura nostra 30.

Differs from the nominate variety by ellipsoid semicells and (slightly) convergent spines. Cell length without spines $37-42 \mu \mathrm{m}$, cell breadth without spines $30-38 \mu \mathrm{m}$, cell thickness $27-28$ $\mu \mathrm{m}$. Maximum length of spines $18 \mu \mathrm{m}$. - Type: our Fig. 30. Type locality: shore of Lake Nabugabo, Uganda (sample 2007-021), A. van Geest, July 28, 2007.

The pluriradiate species Staurodesmus eckertii, as originally described by FöRSTER (1964) from Brazil differs from the roughly similar Std. calyxoides (Wolle) Croasdale, primarily known from North America, by a higher degree of radiation, a wider opened sinus and about parallel (versus divergent) spines. However, since then, of both species a number of varieties have been described that are more or less intermediate in morphology. Compare, e.g., Std. eckertii var. convexus forma divergens described by THÉRÉzIEN (1985) from French Guyana and Std. calyxoides forma major described by Bourrelly \& Couté (1991) from Madagascar. Considering the original diagnoses, the algal form represented in our Figs 30-31 better fits Std. eckertii than Std. calyxoides, so is described as a variety of the former species.

Std. eckertii was not recorded from Africa before whereas the somewhat resembling Std. calyxoides var. major described by BOURRELLY \& Couté (1.c) is the only African record of Std. calyxoides. So, obviously, the main point of distribution of both species is on the American continents. On the Nabugabo site, Std. eckertii var. africanus was only incidentally encountered in sample 2007-021 (Sphagnum).

\section{Staurastrum capitulum BRÉBISSON ex RALFS}

British Desmidieae: 214, pl. 35: 25 (1848).

var. foersteri Coesel et VAN GeEst var. nov. (Fig. 32)

Diagnosis: Differt a varietate typica cellulis 4-radiatis angulis apicalibusin processus brevissimosplusminusve truncatos productis. Cellularum longitudo 32-41 $\mu \mathrm{m}$, latitudo 20-29 $\mu$ m, isthmi latitudo 12-13 $\mu$ m. - Typus: Figura nostra 32.

Differs from the nominate variety by 4-radiate cells whose apical angles are produced into very short, more or less truncate processes. Cell length 32-41 $\mu \mathrm{m}$, cell breadth $20-29 \mu \mathrm{m}$, breadth of isthmus $12-13 \mu \mathrm{m}$. - Type: our Fig. 32. Type locality: shore of Lake Nabugabo (sample 2007022), A. van Geest, July 28, 2007.

The algal form represented in our Fig. 32 agrees with those depicted by FörSTER (1963, 1964) from Brazil under the name of Staurastrum capitulum var. tumidiusculum (NoRDST.) W. et G.S.West. However, var. tumidiusculum as originally described by NORDSTEDT (1888a) from New Zealand is characterized by acuminate apical angles, whereas the apical angles in var. foersteri are produced into (very) short, more or less truncate processes. In respect of that latter feature there is much resemblance with given forms of Staurastrum donnellii Wolle, in particular $S$. donnellii var. ornatum described by BOURRELLY \& Leborme (1946) from Madagascar. 
S. capitulum var. foersteri is especially known from South America but, maybe, is also in Africa more widely distributed. The picture of $S$. capitulum var. acanthophorum NORDST. recorded by BOURRELLY \& COUTÉ (1991) from Madagascar obviously does not refer to var. acanthophorum but to our newly described taxon. On the Nabugabo site, $S$. capitulum var. foersteri was only occasionally encountered in sample 2007-22 (Sphagnum).

\section{Staurastrum corbula W. et G.S.WEST}

J. Bot. 35: 179, pl. 369: 2 (1897).

var. pulchrum W. et G.S.West (Figs 33-34)

J. Bot. 35: 179, pl. 369: 3 (1897).

The algal form represented in our figures very well agrees with Staurastrum corbula var. pulchrum as described by West \& West (1897) from Angola. The variety in question differs from the nominate variety by a concave apex and lateral sides that are indented in the mediane part. No doubt, $S$. corbula is closely affiliated if not identic to $S$. welwitschii described by WEST \& WEST (1.c.) in that same paper. Both $S$. corbula and $S$. welwitschii are only known from Africa and obviously pretty rare. Apart from S. welwitschii recorded by BOURRELLY \& LEBOIME (1946) from Madagascar and S. corbula var. simplex described by Bourrely \& Couté (1991), also from Madagascar, no other finds could be traced. On the Nabugabo site, S. corbula var. pulchrum was frequently encountered in the Sphagnum samples.

Staurastrum longicolle (GRÖNBLAD et A.M.Scott) Coesel et Van Geest stat. nov. (Figs 6-12, 35-36)

Basionym: Staurastrum unicorne var. longicolle GRÖNBLAD et A.M.SCOTT

Acta Bot. Fennica 58: 43, pl. 20: 295-298, pl. 29: 404 (1958).

Typus: Tabula 20: 298.

We herewith validate the name of the abovementioned variety because in the above paper indication of a nomenclatural type is wanting (Art. 37.1 ICBN).

Staurastrum longicolle is a characteristic species, hardly to be confused with any other desmid species. Originally, it was described as a variety of $S$. unicorne W.B.TURNER (GRÖNBLAD et al. 1958). It is true, the shape of the swollen ends of the processes furnished with a prominent, single, obliquely disposed spine is similar in both taxa, but the shape of the semicell body is distinctly different. Moreover, whereas $S$. unicorne is known from several countries in the Indomalaysian/Northern Australian region (e.g., Turner 1892; West \& West 1902; Scott \& PRESCOTt 1958), S. longicolle is exclusively known from tropical Africa. Remarkably, TeILING (1967) in his monography on the genus Staurodesmus listed S. unicorne var. longicolle as Staurodesmus unicornis var. gracilis forma longicollis but it is quite obvious that our taxon under discussion with its long, arm-like processes has to be considered a Staurastrum, not a Staurodesmus species. As is shown in our Figs 6-12, the marked spine at the end of the arm-like processes may be reduced to such a degree that it is almost wanting. Whereas those spines were found to be well developed in cells collected from perifyton on the roots of reed (Figs $7,9,11)$, they were highly reduced in the majority of cells collected from plankton. Strikingly, those latter cells at the end of the processes produced gelatinous, bar-like extrusions which, at first glance, are easily to be interpreted as spines (Figs $8,10,12)$.

Up to then, S. longicolle was only known from Sudan (GRÖNBLAD et al. 1958), Zambia (ThOMASSON 1960) and Madagascar (BouRrelly \& Couté 1991). On the Nabugabo site, $S$. longicolle was the dominant desmid species in the plankton samples but was also frequently encountered in sample 2007-017 (submerged roots of reed).

Staurastrum trihedrale Wolle (Figs 5, 37)

Bull. Torr. Bot. Club 10: 20, pl. 27: 20 (1883).

Although simple in shape and lacking a distinct cell wall ornamentation, Staurastrum trihedrale is readily to be identified. Wolle (1883), when describing this species from Massachusetts, characterized the cells as being 'punctate, granulate'. This circumscription suggests a scrobiculate cell wall, rather than a truly granulate one. As a matter of fact, WoLLE (1.c.) did not picture any cell wall granules, neither is this the case in any later publication dealing with this species. On the other hand, as is shown in a SEM picture of our material (Fig. 5) the cell wall is most coarsely scrobiculate. In addition to that, our pictures show a characteristic apical depression, a feature that may also be noticed in pictures by FöRSTER (1963) and Williamson (1994). Of $S$. trihedrale various varieties have been described which seem to represent but taxonomically insignificant forms. 
S. trihedrale is particularly known from the American continents (e.g., Prescott et al. 1982) but it has also been recorded from Asia (HIRANO 1953; Hinode 1960), New Zealand (Skuja 1976) and Africa. As for the latter continent most finds are from South Africa (Fritsch 1914; ClaAsSEN 1961; Williamson 1994) but there is also a record from Madagascar (BouRRELly \& LEBOIME 1946). On the Nabugabo site, S. trihedrale was infrequently encountered in samples 2007-018, 2007-020 and 2007-021 (all Sphagnum).

Spondylosium rectangulare (WoLLE) W. et G.S.West (Fig. 38)

Trans. Linn. Soc. London, Bot. 5: 231, pl. 12: 13, 14 (1896).

Spondylosium rectangulare is a large-sized, characteristically shaped taxon that can hardly be confused with any other Spondylosium species. It is widely distributed on the American continents (e.g., Croasdale et al. 1983) but, as far as could be traced, from Africa but a single record was known, i.e. from Lake Shiwa Ngandu in Zambia (Thomasson 1966). On the Nabugabo site, only one filament of Spondylosium rectangulare was encountered in sample 2007-20 (Sphagnum).

\section{Discussion}

As compared with the number of species found in the reed and the bog samples (some 81 in the Sphagnum samples and 25 in the reed sample) the number of species encountered in the open water of Lake Nabugabo (about 10) is low. As mentioned earlier, exclusively planktonic desmid species are relatively rare. WEST \& WeST (1909) on a total of 236 desmid species encountered in British softwater lakes classify only 14 of them as being exclusively confined to the plankton.

Coesel \& Meesters (2007) provide a list of 831 desmid taxa found in the Netherlands, 511 of which are classified for a given life form. Only 20 of these 511 taxa (4\%) are marked as euplanktonic, most of them being characteristic of eutrophic waters. Also in the list of desmid species recently provided for the Czech Republic (Š́̆ASTNÝ 2010) only 18 out of 526 taxa are marked as exclusively planktonic. The low percentage of planktonic desmid species may be explained from the overall large cell dimensions in this group of algae causing high sinking rates.
Consequently, in limnetic habitats only desmid species with a high cell surface area/volume ratio, so a high form resistance, are to be expected. Generally speaking, those will have relatively small cell dimensions and/or relatively long processes.

Despite the ability of a number of desmid species to flourish in a limnetic habitat, in temperate climatic regions these algae but seldom quantitatively dominate the phytoplankton assembly, even when oligotrophic softwater lakes are considered (BRoOK 1981). It has been recognized, however, that the quantitative importance of planktonic desmids in tropical lakes is higher than in temperate ones (e.g., Biswas 1929; HuZAR \& ReYNolds 1997). A possible explanation for this may be found in the phenomenon of atelomixis: diurnal mixing of the water column resulting from high differences in air temperature between day and night. By these turbulences the risk of sinking of desmid cells is substantially diminished (BARBOSA \& PADISAK 2002).

The quantitative predominance of desmids as encountered in the plankton of Lake Nabugabo fits this experience. Interestingly, the most dominant desmid species in the plankton, i.e. Staurastrum longicolle, showed a consistent reduction of the large spine at the end of the cell processes characteristic of this species, whereas that spine was well developed in the benthic specimens of $S$. longicolle collected in the nearby reed zone. This might be viewed in the light of speciation of originally benthic life forms in a limnetic environment. WEST \& WEST (1909) suggest that the process of morphological adaptation to pelagic conditions is a gradual one, occupying a long period of evolution, Ввоок (1959), on the contrary, is of opinion that the plasticity of the desmid cell allows a rapid adaptation to the planktonic habitat taking place annually. These two theories need not be per se contrary but could be complementary. What starts as a phenotypic variation may get a genetical base in the course of a longer time period. To get more insight in the nature of the morphological differences within S. longicolle as noticed above, a much more extensive investigation covering the large marshes on the southern border of Lake Nabugabo and some of the adjacent smaller lakes is needed.

When considering the desmid species composition of the Sphagnum samples one of the most striking findings is that the predominant 
species, viz. Actinotaenium cucurbita, Haplotaenium minutum and Tetmemorus laevis, belong to the most common species in Sphagnum peatland in temperate regions too (e.g., COESEL 1975). Possibly this may be related to the low trophic state and low $\mathrm{pH}$ characteristic of Sphagnum vegetation creating rather extreme environmental conditions which are optimal to but a relative low number of species. A more extreme example of this phenomenon is the occurrence of a characteristic alpine desmid flora which is not confined to the European mountains but also known from high mountains in tropical Africa, South America and Asia (Coesel 1996).

Next to the above-mentioned, predominant species we did find (in lower quantities) a series of other desmid taxa in the Sphagnum samples, among which quite a number that may be considered African endemics. Yet, with a total of about 80 taxa our output is distinctly lower than that mentioned by LiND (1971) who recorded 180 taxa. According to the description of her sampling sites, those were former sand pits vegetated by plant species such as Nymphaea, Phragmites, Cyperus, Typha and Utricularia indicating more mesotrophic conditions which form the optimal habitat to desmids (COEsel \& MEesters 2007).

\section{Acknowledgements}

We are much obliged to Dr A. Veen and Dr F.A.C. Kouwets (Waterdienst, Lelystad) for offering SEM facilities and to Dr J.F. Veldkamp (Nationaal Herbarium Nederland, Leiden branch) for Latin translation of the diagnoses. A.M.T. Joosten is acknowledged for help with the identification of some cyanophyte genera.

\section{References}

Barbosa, F.A.R. \& Padisak, J. (2002): The forgotten lake stratification pattern: atelomixis, and its ecological importance. - Int.Vereinigung Theor. Limnol. Verh. 28: 1385-1395.

Biswas, K.P. (1929): Papers on Malayan aquatic biology IV. Freshwater algae. - J. Fed. Malay States Mus. 14: 404-435, 479-481.

Bourrelly, P. (1957): Algues d'eau douce du Soudan Français, région du Macina (A. O. F.). - Bull. Inst. Franç. Afr. Noire, Sér. A, 19: 1047-1102.

Bourrelly, P. (1961): Algues d'eau douce de la République de Cote d'Ivoire. - Bull. Inst. Franç. Afr. Noire, Sér. A, 23: 283-398.

Bourrelly, P. \& Couté, A. (1991): Desmidiées de Madagascar (Chlorophyta, Zygophyceae). -
In: Cramer, J. (ed.): Bibliotheca Phycologica 86. - 349 pp., Gebrüder Borntraeger Verlagsbuchhandlung, Berlin/Stuttgart.

Bourrelly, P. \& Leboime, R. (1946): Notes sur quelques algues d'eau douce de Madagascar. Biol. Jaarb. 13: 75-111.

Brook, A.J. (1959): The status of desmids in the plankton and the determination of phytoplankton quotients. - J. Ecol. 47: 429-445.

Brook, A.J. (1981): The Biology of Desmids. - In: BurnetT, J.H. (ed.): Botanical Monographs 16. - 276 pp., University of California Press, Berkeley/Los Angeles.

Chapman, L.J.; Balirwa, J.; Bugenyi, F.W.B.; Chapman, C. \& CRisman, T.L. (2001): Wetlands of East Africa: Biodiversity, exploitations, and policy perspectives. - In: GOPAL, B.; JUNK, W.J. \& DAvis, J.A. (eds): Biodiversity in Wetlands: Assessment, Function, and Conservation, Vol. 2. - pp. 101-132, Backhuys Publisher, Leiden.

Cheng, D.N.K. (2006): Weather information for Entebbe. - World Meteorological Organization (http://www.worldweather.org). Cited March $12,2011$.

Claassen, M.I. (1961): A contribution to our knowledge of the freshwater algae of the Transvaal Province. - Bothalia 7: 559-666.

Coesel, P.F.M. (1975): The relevance of desmids in the biological typology and evaluation of fresh waters. - Hydrobiol. Bull. 9: 93-101.

Coesel, P.F.M. (1994): On the ecological significance of a cellular mucilaginous envelope in planktic desmids. - Algological Studies 73: 65-74.

Coesel, P.F.M. (1996): Biogeography of desmids. Hydrobiologia 336: 41-53.

Coesel, P.F.M. \& Meesters, J. (2007): Desmids of the Lowlands. Mesotaeniaceae and Desmidiaceae of the European Lowlands. - 351 pp., KNNV Publishing, Zeist, The Netherlands.

Croasdale, H.; Bicudo, C.E.M. \& Prescott, G.W. (1983): A Synopsis of North American desmids, Part 2, Section 5. - 117 pp., University of Nebraska Press, Lincoln/London.

Efitre, J.; Chapman, L.J. \& Makanga, B. (2001): The inshore benthic macroinvertebrates of Lake Nabugabo, Uganda: seasonal and spatial patterns. - African Zoology 36: 205-216.

FÖRSTER, K. (1963): Desmidiaceen aus Brasilien. 1. Rev. Algol. 7: 38-92.

FÖrSTER, K. (1964): Desmidiaceen aus Brasilien. 2. Hydrobiologia 23: 321-505.

FÖrster, K. (1982): Conjugatophyceae: Zygnematales und Desmidiales (excl. Zygnemataceae). - In: Huber-Pestalozzi, G. (ed.): Das Phytoplankton des Süsswassers, 8. Teil, 1. Hälfte. - 543 pp., E. Schweizerbart'sche Verlagsbuchhandlung, Stuttgart.

FritsCh, F.E. (1914): Contributions to our knowledge 
of the freshwater algae of Africa. I. - Ann. Biol. Lacustre 7: 40-59.

GRÖNBLAD, R. (1945): De algis Brasiliensibus, praecipue Desmidiaceis, in regione inferiore fluminis Amazonas a Professore August Ginzberger (Wien) anno 1927 collectis. - Acta Soc. Sci. Fenn., Ser. B, Opera Biol. 2: 1-43.

Grönblad, R.; Prowse, G.A. \& Scott, A.M. (1958): Sudanese desmids. - Acta Bot. Fennica 58: $1-82$.

Grönblad, R.; Scott, A.M. \& Croasdale, H. (1964): Desmids from Uganda and Lake Victoria. Acta Bot. Fenn. 66: 1-57.

Hieronymus, G. (1895): Klasse Conjugatae. - In: Engler, A. (ed.): Die Pflanzenwelt Ost-Afrikas und der Nachbargebiete. - pp. 19-21, D. Reimer, Berlin.

Hinode, T., (1960): On some Japanese desmids 2. Hikobia 2: 61-64.

Hirano, M. (1953): The alpine desmids from the Japanese Alps. 2. - Bot. Mag. (Tokyo) 66: 205210.

Huszar, V.L.M. \& Reynolds, C.S. (1997): Phytoplankton periodicity and sequences of dominance in an Amazonian flood-plain lake (Lago Batata, Pará, Brazil): responses to gradual environmental change. - Hydrobiologia 346: 169-181.

Kling, H.J.; Almond, J.; Mugidde, R. \& Hecky, R.E.. (2006): Phytoplankton of satellite lakes of Lake Victoria Basin Uganda, Africa. Poster Presentation. - Great Lakes of the World Symposium (GLOW IV), Dar Es Salam, Tanzania.

KrIEger, W. (1937): Die Desmidiaceen Europas mit Berücksichtigung der aussereuropäischen Arten. - In: RABENHORST's Kryptogamenflora von Deutschland, Österreich und der Schweiz 13, Abt. 1, Teil 1. - 712 pp., Akademische Verlagsgesellschaft, Leipzig.

KrIEgER, W. (1939): Die Desmidiaceen Europas mit Berücksichtigung der aussereuropäischen Arten. - In: RABENHORST's Kryptogamenflora von Deutschland, Österreich und der Schweiz 13, Abt. 1, Teil 2. - 117 pp., Akademische Verlagsgesellschaft, Leipzig.

KRIEGER, W. (1950): Desmidiaceen aus der montanen Region Südost-Brasiliens. - Ber. Deutsch. Bot. Ges. 72: 35-42.

Lind, E. (1971): Some desmids from Uganda. - Nova Hedwigia 22: 535-585.

McNeILl, J. et al. (2006): International Code of Botanical Nomenclature (Vienna Code) adopted by the Seventeenth International Congress Vienna, Austria, July 2005. Regnum veg. 146, - 568 pp., A.R.G. Gantner Verlag, Ruggel/ Liechtenstein.

Nordstedt, O. (1888a): Freshwater algae collected by
Dr S. Berggren in New Zealand and Australia. - Kongl. Svenska Vetenskapsakad. Handl. 22: $1-98$.

Nordstedt, O. (1888b): Desmidieer från Bornholm. Vidensk. Meddel. Naturh. Forening Kjøbenhavn 1888: 188-213.

Opute, F.I. (1992): Contribution to the knowledge of algae of Nigeria. I. Desmids from the Warri/ Forcados Estuaries. II. The genera Euastrum and Micrasterias. - Algological Studies 65: 73-92.

Prescott, G.W.; Bicudo, C.E.M. \& Vinyard, W.C. (1982): A Synopsis of North American desmids, Part 2, Section 4. - 700 pp., University of Nebraska Press, Lincoln/London.

RAMSAR (2003): Lake Nabugabo wetland system. Information sheet on Ramsar Wetlands (RIS). The Ramsar Convention on Wetlands (http:// www.ramsar.org). Cited March 12, 2011.

RŮŽıČKA, J. (1981): Die Desmidiaceen Mitteleuropas, Band 1, 2. Lieferung. - pp. 293-736, E. Schweizerbart'sche Verlagsbuchhandlung, Stuttgart.

RŮŽIČKA, J. \& PouZAR, Z. (1978): Erwägungen über die Taxonomie und Nomenklatur der Gattung Actinotaenium Teil. - Folia Geobot. Phytotax. 13: 33-66.

Schmidle, W. (1898): Die von Professor Dr. Volkens und Dr. Stuhlmann in Ost-Afrika gesammelten Desmidiaceen. - Bot. Jahrb. Syst. 26: 1-59.

Schmidle, W. (1902): Algen, insbesondere solche des Plankton, aus dem Nyassa-See und seiner Umgebung, gesammelt von Dr. Fülleborn. Bot. Jahrb. Syst. 32: 55-88.

Scott, A.M. \& Prescott, G.W. (1958): Some freshwater algae from Arnhem Land in the Northern Territory of Australia. - Rec. AmericanAustralian Sci. Exped. Arnhem Land 3: 8-136.

SkujA, H. (1976) Zur Kenntnis der Algen Neuseeländischer Torfmoore. - Nova Acta Regiae Soc. Sci. Upsal., Ser. V: C, 2: 1-159.

ŠŤAstnÝ, J. (2010) Desmids (Conjugatophyceae, Viridiplantae) from the Czech Republic; new and rare taxa, distribution, ecology. - Fottea 10: $1-74$.

TeILING, E. (1967): The desmid genus Staurodesmus. Ark. Bot. 6: 467-629.

THÉRÉzIEN, Y. (1985): Contribution à l'étude des algues d'eau douce de la Guyane Française, å l'exclusion des diatomées. - In: CrAmer, J. (ed.): Bibliotheca Phycologica 72. - 275 pp., Gebrüder Borntraeger Verlagsbuchhandlung, Berlin/Stuttgart.

Thomasson, K. (1960): Notes on the plankton of Lake Bangweulu. 2. - Nova Acta Regiae Soc. Sci. Upsal., Ser. 4, 17: 1-43.

Thomasson, K. (1966): Phytoplankton of Lake Shiwa Ngandu. - Expl. hydrobiol. Bangweolo- 
Luapula 4: 1-91.

Thomasson, K. (1986): Algal vegetation in North Australian billabongs. - Nova Hedwigia 42: 301-378.

Turner, W.B. (1892): Algae aquae dulcis Indiae orientalis. - Kongl. Svensk. Vetensk. -Akad. Handl. 25: 1-187.

VAN BreEmen, N. (1995): How Sphagnum bogs down other plants. - Tree 10: 270-275.

VAN OYE, P. (1953): Contribution à la connaissance des Desmidiées du Congo belge. - Hydrobiologia 5: 239-308

West, G.S. (1907): Report of the freshwater algae, including phytoplankton, of the Third Tanganyika Expdition conducted by Dr. W.A. Cunnington, 1904-1905. - J. Linn. Soc. Bot. 38: 81-197.

West, W. \& West, G.S. (1896): On some North American Desmidieae. - Trans Linn. Soc. London, Bot. 5: 229-274.

West, W. \& West, G.S. (1897): Welwitsch's African freshwater algae. XI. Desmidiaceae. - J. Bot. 35: 77-89, 113-122, 172-183, 235.
West, W. \& West, G.S. (1902): A contribution to the freshwater algae of Ceylon. - Trans. Linn. Soc. London, Bot. 6: 123-215.

West, W. \& West, G.S. (1905): A Monograph of the British Desmidiaceae. Vol. 2. - 206 pp., The Ray Society, London.

West, W. \& West, G.S. (1909): The British freshwater phytoplankton with special reference to the desmid plankton and the distribution of British desmids. - Proc. Roy. Soc. London, Ser. B, Biol. Sci. 81: 165-206.

Williamson, D.B. (1994): A contribution to the knowledge of the desmid flora of South Africa and the adjoining states of Ciskei and Swaziland. - Arch. Hydrobiol./Suppl. 99: 415-487.

Wolle, F. (1883): Freshwater algae. VII. - Bull. Torr. Bot. Club 10: 13-21.

(C) Czech Phycological Society (2012)

Received May 15, 2011

Accepted July 18, 2011 